\title{
An interdisciplinary, student-active course on UN Sustainable Development Goal 14: Life below water
}

\author{
K. Enberg, Department of Biological Sciences, University of Bergen
}

\begin{abstract}
Educating students to respond to Sustainable Development Goals (SDGs) calls for teaching and learning where students are at the centre of their own learning. Sustainability questions are 'wicked problems', where no single, correct answer exists, but the answers depend on the values of those who answer, and require innovative pedagogy and active, action-oriented learning allowing the learners to think critically and engage in exploring sustainable futures. Sustainable Development Goal 14, Life Below water, aims at "conserving and sustainably using the oceans, seas and marine resources for sustainable development". Along with the 16 other SDGs, it provides an excellent focus point for teaching and learning. The course SDG214 at the Department of Biological Sciences at the University of Bergen is a 10 ECTS open interdisciplinary course where the students work in teams, and the portfolio assessment includes essays, presentations, a debate, a poster and a paper, but no exam. The assessment is formative and the students get feedback on their individual and group assignments and are allowed to resubmit. The course culminates in a poster session organised together with other courses. The student feedback suggests that course functions well for education for sustainable development.
\end{abstract}

\section{INTRODUCTION}

\subsection{Sustainability education}

Educating students to respond to Sustainable Development Goals (SDGs) calls for teaching and learning where students are at the centre of their own learning, including learning methods such as problembased learning, role plays and simulations, group discussions, debates, and case studies (Byrne 2000; Cotton \& Winter 2010; Tilbury 2011; UNESCO 2018; Wiek et al. 2011). Sustainability questions are often 'wicked problems' (Rittel \& Webber 1973), where no single, correct answer exists, but the answers depend on the values of those who are asked. Education centred around such questions require innovative pedagogy and active, action-oriented learning allowing the learners to think critically and engage in exploring sustainable futures (UNESCO 2018, SDSN 2020).

\subsection{Motivation for SDG214 UN Sustainable Development Goal 14: Life Below Water}

University of Bergen has a strong marine profile, and was in 2018 announced as both the official United Nations Academic Impact (UNAI) Hub for SDG14 - Life below water, and as the leader of the SDG14 Cluster for the International Association of Universities (IAU). However, as often happens, the establishment of the SDG214 course was strongly based on a personal motivation of the teacher, in this case the author, to teach on a subject of high relevance for students and society at large.

\section{COURSE DESIGN AND DEVELOPMENT}

\subsection{General principles}

\subsubsection{Active learning}

It was clear from the outset that SDG214 would be based on highly student-active learning methods, not only because the learning benefits are clear (e.g., Freeman et al. 2014), but also because making students active players in their learning is particularly well suited for education for sustainable development (UNESCO 2018, SDSN 2020). Active learning implies that students are learning by engaging in (cognitive) activity, and constructing rather than receiving knowledge (Bransford, Brown \& Cocking 2000; Chickering and Gamson 1987; Johnson, Johnson \& Smith 1998; Prince 2004), leading to deep approach to learning (Bevan et al. 2014). 


\subsubsection{Constructive alignment}

One of the benefits of designing a completely new course is the ease of paying attention to constructive alignment (Biggs 1996). Starting from the end - "what do I want my students to learn?" - allows for the intended learning outcomes to articulate the teacher's intentions for the course (Biggs 1996; BoultonLewis 1995). Starting from the intended learning outcomes, the alignment was drawn through learning activities to assessment, and Table 1 and Table 2 describe the intended learning outcomes and the associated assignments.

\subsubsection{Authentic assessment}

Whenever possible, SDG214 uses authentic assessment (Kearney et al. 2013) where the assessment method actually allows for testing the intended learning. For example, it would feel quite unnatural if for getting a driving licence one would only write an essay about driving a car, and not actually demonstrate that one can drive a car. Traditionally, assessment in higher education is often somewhat like this, with a written exam or a multiple choice test at the end of the course, with potentially weak connections along the axis from learning outcomes via activities to assessment. In the development of SDG214, special attention was put on making sure that the assessment was as authentic as possible, for example by using assignments such as presentations, debates, peer-reviews, and reflective essays (see Table 1 and Table 2 for more details).

\subsubsection{Formative feedback and assessment}

Throughout SDG214, the students receive formative feedback, where this information intends to change their behaviour or thinking with the goal of improved learning (Shute 2008). In addition to this, we also apply formative assessment where assessment is seen as part of the learning process (Sadler 1989, Nicol \& Macfarlane-Dick 2006), not just a measuring tool for students' acquirement of intended learning goals (so called summative assessment, Taras 2005). Feedback is provided by both the teachers and teaching assistants as well as by peers. Peer feedback has positive effects of both the students providing and the ones receiving the feedback (e.g. Boud et al., 1999), and the ability to give critical but constructive peer feedback is a central transferable skill for almost any thinkable career choice. Formative feedback and assessment, particularly when done throughout the whole course and not only at the end, give the students a realistic view of the level of their knowledge and skills and provides them with clear view of what they still need to work on. This is an element that the student evaluations have shown the students appreciate highly.

Table 1. Intended learning outcomes, and which assignments are assessing students achievement of them. The bold $\mathbf{X}$ shows the main assignment for a given learning outcome.

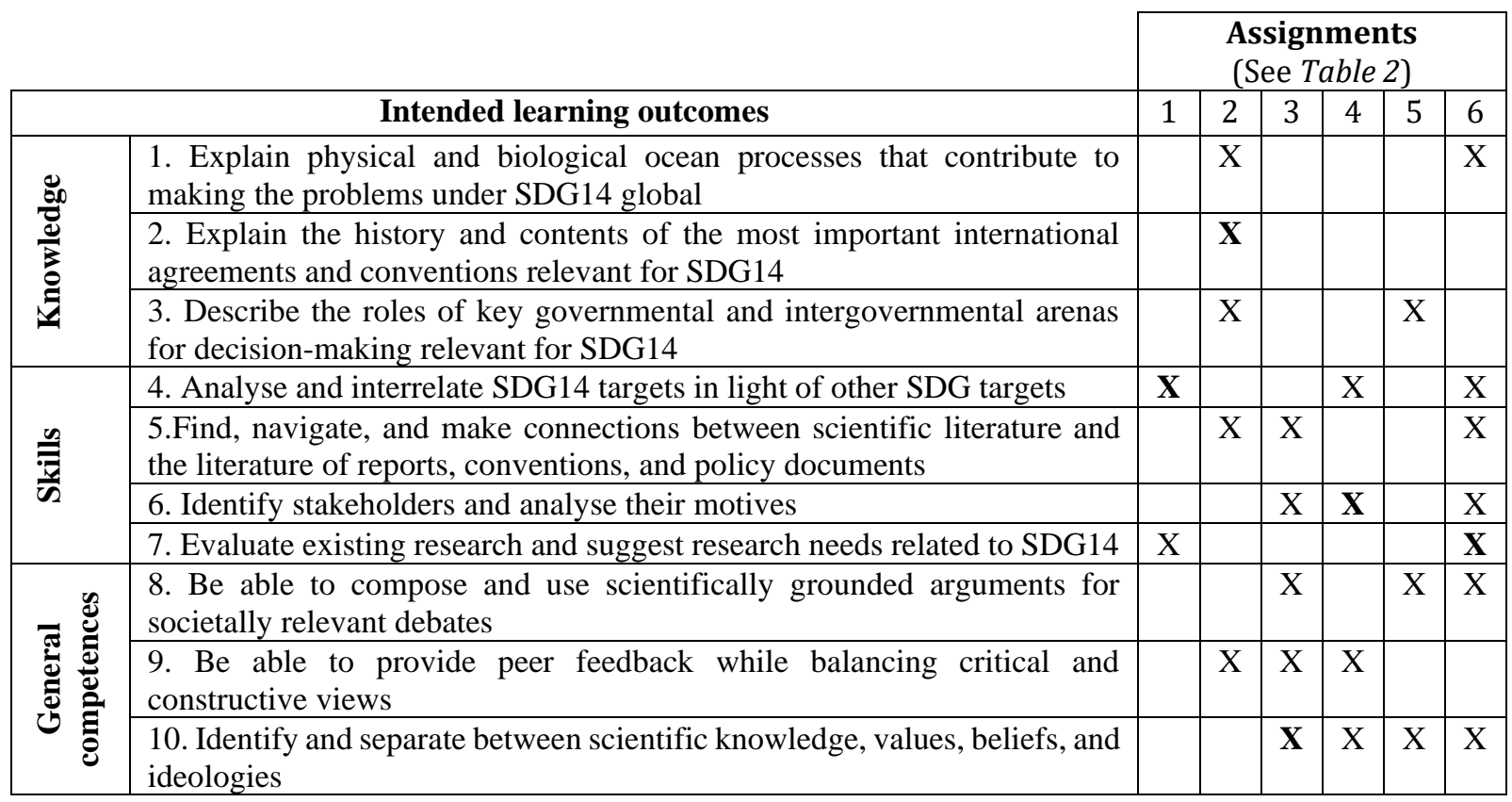




\subsection{Learning outcomes, activities and assessment}

General learning outcomes for SDG14 have been drafted by for example UNESCO (2017), but for SDG214 an independent set of learning outcomes was designed (Table 1). Table 2 lists the assignments associated with the different learning outcomes and also shortly describes the learning activities. The course is graded as pass/fail, but all assignments have in the first years been graded with points, and Table 2 lists the maximum points for each assignment.

Table 2. Assignments, associated learning outcomes (see Table 1 for details; the one marked with bold is the main learning outcome for a given assignment), and the maximum points for each assignment.

\begin{tabular}{|c|c|c|c|}
\hline Assignment description & Specifications & $\begin{array}{c}\text { Learning } \\
\text { outcome }(s)\end{array}$ & Points \\
\hline $\begin{array}{l}\text { 1. Identify SDG14 trade-offs and } \\
\text { conflicts (group discussion, } \\
\text { individuals essay) }\end{array}$ & $\begin{array}{l}\text { Individual essay discussing the trade-offs and conflicts } \\
\text { of SDG14 with the other SDGs (500-1000 words). }\end{array}$ & 4,7 & 12 \\
\hline $\begin{array}{l}\text { 2. Agreements, conventions, } \\
\text { reports, research (group } \\
\text { presentation) }\end{array}$ & $\begin{array}{l}\text { Each group chooses one of the SDG14 targets and } \\
\text { tracks it back in time, and prepares a 10-minute } \\
\text { presentation to be presented in class. }\end{array}$ & $2,1,3,5,9$ & 12 \\
\hline $\begin{array}{l}\text { 3. Describe an NGO and its use of } \\
\text { science (group discussions \& } \\
\text { presentation) }\end{array}$ & $\begin{array}{l}\text { Each group chooses an NGO relevant for SDG14, and } \\
\text { studies \& discusses its use of science (web pages, } \\
\text { publications, campaigns), and presents their findings to } \\
\text { the class in 10-minute presentation. }\end{array}$ & $\mathbf{1 0}, 5,6,8,9$ & 12 \\
\hline $\begin{array}{l}\text { 4. Analyse stakeholders (group } \\
\text { discussions, individual essay) }\end{array}$ & $\begin{array}{l}\text { Write a 500-1000 word individual essay describing the } \\
\text { stakeholders and their motives in the film 'Cod Is } \\
\text { Dead'. }\end{array}$ & $6,4,9,10$ & 12 \\
\hline $\begin{array}{l}\text { 5. Recreate a current debate } \\
\text { (group debate)* }\end{array}$ & Preparation and participation in Oxford-type debate. & $\mathbf{8}, 3,10$ & \\
\hline 6a. Final poster (group work) & $\begin{array}{l}\text { Each group makes a poster on a theme relevant for } \\
\text { SDG14. The team members will evaluate their own } \\
\text { and each others' contribution towards the team work. }\end{array}$ & $\begin{array}{l}1,4,5,6,7,8 \\
10\end{array}$ & 14 \\
\hline 6b. Final paper (group work) & $\begin{array}{l}\text { Each group makes a 3-page paper on a theme relevant } \\
\text { for SDG14 (to support the poster). The team members } \\
\text { will evaluate their own and each others' contribution } \\
\text { towards the team work. }\end{array}$ & $\begin{array}{l}1,4,5,6,7,8 \\
10\end{array}$ & 14 \\
\hline $\begin{array}{l}\text { P1. Peer-review of your fellow's } \\
\text { assignment on SDG14 trade-offs } \\
\text { and conflicts }\end{array}$ & $\begin{array}{l}\text { Write a peer review of your fellow student's analysis } \\
\text { directly on the word document. Use comments and } \\
\text { track changes. (ca } 300-500 \text { words in total). }\end{array}$ & 9 & 3 \\
\hline $\begin{array}{l}\text { P2. Peer-review of your fellow's } \\
\text { assignment on stakeholders }\end{array}$ & $\begin{array}{l}\text { Write a peer review of your fellow student's analysis of } \\
\text { stakeholders directly on the word document. Use } \\
\text { comments and track changes. (ca 300-500 words in } \\
\text { total). }\end{array}$ & 9 & 3 \\
\hline $\begin{array}{l}\text { a. Network map of SDG } \\
\text { interactions (group discussion, } \\
\text { individual map) }\end{array}$ & $\begin{array}{l}\text { Make a network map of the interactions (positive and } \\
\text { negative) of all the } 17 \text { SDGs. }\end{array}$ & 4 & 2 \\
\hline $\begin{array}{l}\text { b. Participate in SDG Bergen } \\
\text { Conference \& reflect upon your } \\
\text { experience (individual reflection) }\end{array}$ & $\begin{array}{l}\text { Write a } 300 \text {-word reflection of the activity you } \\
\text { participated on. }\end{array}$ & & 2 \\
\hline $\begin{array}{l}\text { c. Reflective short essay on } \\
\text { changes in perception during the } \\
\text { course (group discussion, } \\
\text { individual essay) }\end{array}$ & $\begin{array}{l}\text { First discussions in mixed groups on your perceptions } \\
\text { on sustainability, SDG14, and your perceptions might } \\
\text { have changed during this course. } 300-500 \text { words. To } \\
\text { be done "in class". }\end{array}$ & All & 2 \\
\hline
\end{tabular}

*In 2020 the assignment 5 was changed to an 'op-ed' article on agreed theme due to covid-19 pandemic moving the teaching online. 


\subsection{Evaluation of team members' effort}

Several of the assignments $(2,3,5$, and 6$)$ are done in groups. The students are members of the same team throughout the semester, and these are set up to be as interdisciplinary as possible. To avoid "freeriding" in the group assignments (e.g., Khuzwayo 2018), all team member evaluate their own and their team members efforts towards the group work, independently and anonymous to the other group members, and these evaluations influence the point sum each student receives for a given group assignment. In case of large discrepancies in the perception of effort, the teacher discusses with the team members individually to clarify. The evaluations are usually surprisingly uniform, and the students within the group tend to agree on who did more or less, or if the effort was equal. The goal is that the effort would be equally distributed among the team members.

\subsection{Student feedback and the course development based on it}

In 2019, 18 out of 18 and in 202030 out of 38 students that finished the course also filled the online feedback survey. The student feedback for the course has been in general positive - $85 \%$ and $93 \%$ of the students have been "in general happy with the course" (Fig. 1). The feedback has also been very useful for further development of the course. For example, in 2019 just under a half of the students felt that the expectations for the assignments were clear, and over one third of the students felt they were not clear (Fig. 2). For 2020, rubrics were developed for each assignment, and probably largely due to this, $97 \%$ of the students felt that the expectations were clear (Fig. 2).
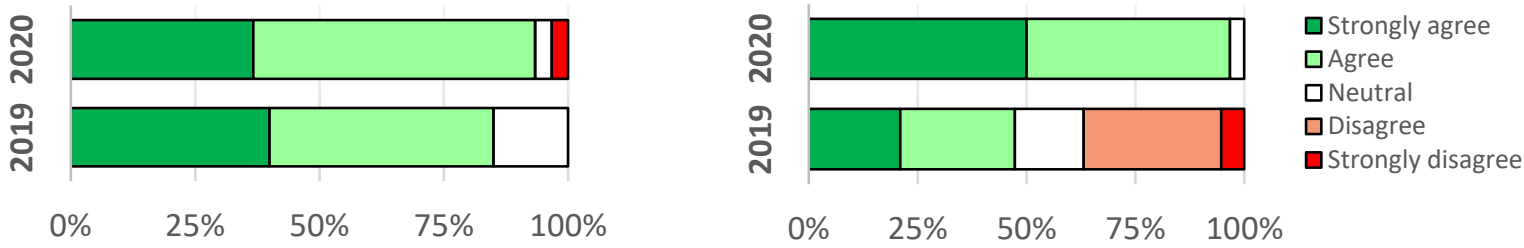

Fig. 1. Statement: "I am in general happy with the course".

Fig. 2. Statement: "Clear expectations were presented for the assignments".

The skills that most of the students feel were developed during the course are critical thinking (Fig. 3), cooperation (Fig. 4) and writing (in 2019 95\% and in 2020 90\% of the students agreed that the course developed their skills in writing - figure not shown).

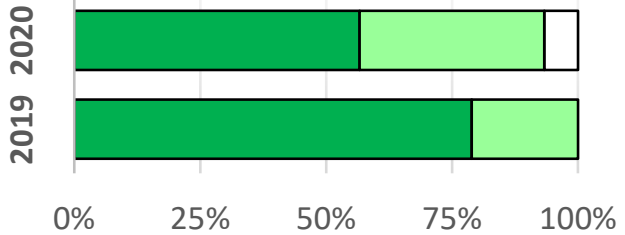

Fig. 3. Statement: "The course developed my skills within critical thinking".

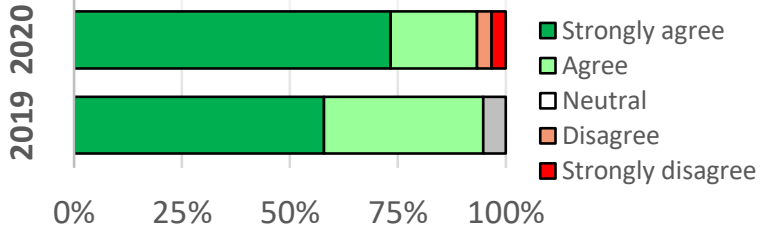

Fig. 4. Statement: "The course developed my skills within cooperation".

\section{CONCLUSIONS}

SDG214 has turned out to be a course that interest a wide range of students. The students also experience improvement in the skills crucial for sustainable development, such as critical thinking and cooperation. The student feedback has been very helpful in developing this relatively new course. The next challenge for this course is that there are about twice as many students that want to take this course than there is capacity for, and we have to develop ways to upscale the active learning elements to a larger class size.

\section{ACKOWLEDGEMENTS}

The author thanks all the guest teachers for their invaluable input for the course, and Christian Jørgensen and Inger E. Måren for many discussions on developing and improving SDG214. 


\section{REFERENCES}

Bevan, S.J. et al. (2014). Diverse Assessment and Active Student Engagement Sustain Deep Learning: A Comparative Study of Outcomes in Two Parallel Introductory Biochemistry Courses. Biochemistry and Molecular Biology Education, 42: 474-479.

Biggs, J. (1996). Enhancing teaching through constructive alignment, Higher Education, 32(3), 347-364.

Boud, D., Cohen, R. \& Sampson, J. (1999) Peer learning and assessment, Assessment and Evaluation in Higher Education, 24(4), 413-426

Boulton-Lewis, G.M. (1995). The SOLO taxonomy as a means of shaping and assessing learning in higher education. Higher Education Research and Development, 14(2), 143-154.

Bransford, J. D., Brown, A. L. and Cocking, R. R. (2000) How people learn, Washington, DC: National academy press.

Byrne, J. (2000). From policy to practice: creating education for a sustainable future. In Wheeler, K.A. \& Bijur A.P. (Eds.) Education for a Sustainable Future: A Paradigm of Hope for the 21 st Century (pp. 35-72). New York: Kluwer/Plenum.

Chickering, A. W. and Gamson, Z. F. (1987) Seven principles for good practice in undergraduate education. AAHE bulletin, 3,7 .

Cotton, D., \& Winter, J. (2010). It's not just bits of paper and light bulbs. A review of sustainability pedagogies and their potential for use in higher education. Sustainability education: Perspectives and practice across higher education, 39-54.

Freeman S. et al. (2014). Active learning increases student performance in science, engineering, and mathematics. PNAS, 111: 8410-8415.

Johnson, D. W., Johnson, R. T. and Smith, K. A. (1998) Cooperative learning returns to college what evidence is there that it works? Change: the magazine of higher learning, 30, 26-35.

Kearney, S. (2013). Improving engagement: the use of 'Authentic self-and peer-assessment for learning'to enhance the student learning experience. Assessment \& Evaluation in Higher Education, 38(7), 875-891.

Khuzwayo, M. E. (2018). Assessment of group work in initial teacher education and training. S. Afr. J. Educ., 38, 11.

Nicol, D. J. and Macfarlane-Dick, D. (2006) Formative assessment and self-regulated learning: a model and seven principles of good feedback practice. Stud. High. Educ., 31, 199-218.

Prince, M. (2004) Does active learning work? A review of the research. Journal of engineering education, 93, 223-231.

Rittel, H.W.J., Webber, M.M. (1973). Dilemmas in a general theory of planning. Policy Science 4: 155-169.

Sadler, D. R. (1989) Formative assessment and the design of instructional systems, Instructional Science, 18, 119144.

SDSN (2020): Accelerating Education for the SDGs in Universities: A guide for universities, colleges, and tertiary and higher education institutions. New York: SDSN.

Shute, V. J. (2008) Focus on formative feedback. Rev. Educ. Res., 78, 153-189.

Taras, M. (2005) Assessment - Summative And Formative - Some Theoretical Reflections. British Journal of Educational Studies, 53: 466-478

Tilbury, D. (2011). Education for sustainable development: An expert review of processes and learning. Paris: UNESCO.

UNESCO (2017). Education for Sustainable Development Goals. Learning Objectives. ISBN 978-92-3-1002090 .

UNESCO (2018). Issues and Trends in Education for Sustainable Development. UNESCO Digital Library: Paris, France, 2018; ISBN 978-92-3-100244-1

Wiek, A. et al. (2011). Key competencies in sustainability: A reference framework for academic program development. Sustainability Science, 6, 203-218. 